\title{
The Classification of Staphylococci and Micrococci from World-wide Sources
}

\author{
By A. C. BAIRD-PARKER \\ Unilever Research Laboratory, Colworth House, Sharnbrook, Bedford
}

(Received 21 September 1964)

\begin{abstract}
SUMMARY
A study has been made of 607 cultures of Gram-positive and catalasepositive cocci received from workers and collections in different parts of the world. These cultures were examined for a wide range of morphological and physiological characters and representative cultures were further studied to determine the chemical constituents of the organisms. Five hundred and sixty-four of the cultures received were aerobic members of the Micrococcaceae, and of these $96 \%$ were classified in the author's groups and subgroups; a further subgroup was, however, introduced to accommodate the not previously studied pink-pigmented micrococci. It appears that the Gram-positive and catalase-positive cocci are best separated into, the genus Staphylococcus and the genus Micrococcus on the ability of members of Staphylococcus to grow and produce acid from glucose anaerobically; six subgroups of staphylococci were recognized and eight of micrococci. The relationship of named species, groups and subgroups to the author's classification was examined; several species and groups of micrococci had been incorrectly classified. Thus, $M$. denitrificans, $M$. halodenitrificans and $\boldsymbol{M}$. radiodurans possess characters which suggest that they should be reclassified with the Gram-negative genera and that Abd-ElMalek and Gibson's group IIIB should be classified with the Gram-positive microbacteria.
\end{abstract}

\section{INTRODUCTION}

This paper records the study of 607 cultures of non-halophilic Gram-positive and catalase-positive cocci received from workers and collections in different parts of the world. They were examined by using a wide range of physiological tests; representative organisms were further studied to determine their chemical composition. The organisms studied were named species, groups or subgroups that have been maintained in culture collections or were recent isolates which had been sent to the author as Gram-positive and catalase-positive cocci, or as belonging to the genera Micrococcus, Staphylococcus or Sarcina. Included amongst these organisms were the original strains used in the recent classifications of the Gram-positive and catalasepositive cocci by Abd-el-Malek \& Gibson (1948), Shaw, Stitt \& Cowan (1951), Pohja (1960), Anderson (1962), Mossel (1962), and Kocur \& Martinec (1962). The objects of this work were: to apply the author's proposed classification of the Grampositive and catalase-positive cocci (Baird-Parker, 1962, 1963) to strains isolated from a wide range of sources; to compare the characters of named species from different collections and habitats; to establish the relationship between the different taxa proposed in recent classifications of these organisms. 


\section{METHODS}

Table 1 gives the sources of the cultures examined. They had been received on agar slopes or freeze-dried in ampoules. They were checked for purity by plating on the yeast glucose agar described by Baird-Parker (1963) and maintained on slopes of heart-infusion agar stored at $5^{\circ} ; 467$ of these cultures were subsequently freezedried for further study.

$\begin{array}{ccc}\text { Table 1. Source of cultures } & \\ \text { Donor } & \text { No. of } & \begin{array}{r}\text { Description } \\ \text { of cultures }\end{array}\end{array}$

Dr J. I. W. Anderson Professor R. Buttiaux Miss E. Coster

Dr C. M. Cousins

Dr S. T. Cowan

Dr G. H. Davis

Dr R. H. Deibel

Dr E. I. Garvie

Professor N. G. Heatley

Dr A. J. Holding

Miss M. John

North sea
food
miscellaneous
milking equipment
miscellaneous

dental

miscellaneous

miscellaneous

sewage

acid soils

(1) nose

(2) air

Dr M. Kocur

Dr J. Liston

Dr E. J. Lowbury

Dr I. J. McDonald

Mr J. H. H. Mol

Dr D. A. A. Mossel

Professor R. G. E. Murray

Dr F. P. Ninivaara

Mr J. Patterson

Dr D. M. Pilsbury

Dr M. S. Pohja

Dr J. W. Rouatt

Dr H. Williams Smith

Dr J. M. Shewan

Dr M. J. Thornley

Dr K. Warnøe

miscellaneous
sea foods and marine mud
skin burns
Cheddar cheese
dry sausage
food
human
dry sausage
pork, Wiltshire bacon and
brine
human skin
(1) fermented meat products
(2) dry sausage
miscellaneous
chicken, pig, cow, sheep
marine
food
bacon

8 Marine micrococci

4 Staphylococci, micrococci

7 Named species of aerococci, pediococci

6 Gram-positive catalasepositive cocci

85 Named species of micrococci, sarcinas, staphylococci, aerococci, pediococci (NCTC collection*)

6 Staphylococci

3 Micrococcus hyicus; 'denitrifying' staphylococci

40 Named species of micrococci, sarcinas, staphylococci (NCDO collection $\dagger$ )

1 Su's (1948) micrococcinproducing micrococcus

12 Micrococci, sarcinas

21 Coagulase-negative staphylococci

50 Gram-positive catalasepositive cocci

90 Named species of staphylococci, micrococei

20 Staphylococci, micrococci

50 Staphylococci, micrococci

10 Cocci

6 Micrococci

2 Staphylococcus aureus, and a micrococcus

6 'Inhibitory micrococci'

1 Micrococcus M53

139 Gram-positive catalasepositive cocci

4 Staphylococcus albus

11 Representatives of Pohja's (1960) subgroups

4 Micrococci

6 Named Micrococcus spp.

15 S. aureus

10 Micrococci, cocci (NCMB collection $\ddagger$ )

$1 M$. radiodurans

$3 \quad$ S. aureus, S. epidermidis

* National Collection of Type Cultures; $\dagger$ National Collection of Dairy Organisms; $:$ National Collection of Marine Bacteria. 


\section{Examination of morphology and physiological characters}

Morphology was examined in hanging-drop preparations and in smears stained by Gram's method. Organisms for these studies were grown at $30^{\circ}$ and $37^{\circ}$ on yeast glucose agar and nutrient agar, and in nutrient broth. Motility was determined on cultures grown in yeast glucose broth for $6-7 \mathrm{hr}$ at $30^{\circ}$; organisms were subcultured at least once in yeast glucose broth before testing. For studies of physiological characters, organisms were grown at $30^{\circ}$ on yeast glucose agar and then subcultured on nutrient agar. Growth from plates of the latter was used to inoculate bottles of nutrient broth. Tests were done by using the media and methods described by Baird-Parker (1963).

\section{Examination of cell and cell-wall components}

Forty-five strains of Gram-positive, catalase-positive cocci were examined for sugars, amino sugars, amino acids, teichoic acids, peptides and proteins. Bacteria for these studies were grown by inoculating yeast glucose broth $(200 \mathrm{ml}$.) in 11 . conical flasks shaken at 120 oscillations/min. for $18-48 \mathrm{hr}$ at $30^{\circ}$. One 1 . of culture of each organism was grown, giving a yield of 2 to $4 \mathrm{~g}$. wet weight organism. The organisms were washed 3 times with distilled water and then divided into two equal parts. One part was broken to obtain cell-wall and cell-content fractions and the other was used for extracting constituents from whole organisms.

Organisms were broken by shaking with No. 12 ballotini beads at $5^{\circ}$ in a Mickle disintegrator; conditions used were those found optimal by Salton \& Horne (1951). The ballotini beads were removed by filtration through sintered glass filters (No. 1 porosity) and the cell-wall fragments collected by centrifuging the filtrates at $35,000 \mathrm{~g}$ for $10 \mathrm{~min}$. The supernatant fluids, containing the cell contents of the disrupted organisms, were concentrated to $\frac{1}{3}$ volume by dialysis in Visking dialysis tubing against polyethylene glycol (mol. wt. 20,000) at $5^{\circ}$; they were stored at $-20^{\circ}$.

Amino acids. Cell-wall fragments were cleaned by digestion for $18 \mathrm{hr}$ at $37^{\circ}$ in $5 \mathrm{ml}$. of a $0.5 \%(\mathrm{w} / \mathrm{v})$ solution of crystalline trypsin (pH 8.6). These were collected by centrifugation at $35,000 \mathrm{~g}$ for $20 \mathrm{~min}$. and after washing 3 times with distilled water they were hydrolysed with $6 \mathrm{~N}-\mathrm{HCl}$ and further treated by the procedures described by Davis \& Baird-Parker (1959). The amino acids were separated by twodimensional chromatography on Whatman No. 1 filter paper by using the solvent system of Davis \& Freer (1960). The papers were developed by spraying with a solution of ninhydrin $(0 \cdot 25 \%)$ in acetone + water + collidine $(95+5+1$ by vol.) and heating at $105^{\circ}$ for 5-10 min. Isomers of diaminopimelic acid were separated by using the solvent system of Hoare \& Work (1957).

Teichoic acids. The procedures of Armstrong et al. (1958) and Davison \& Baddiley (1963) were used to isolate the teichoic acids. Cell walls $(0.25 \mathrm{~g}$. wet wt.) were treated as described by these authors and the purified material containing teichoic acid hydrolysed in $4 \mathrm{~N}-\mathrm{HCl}$ for $6 \mathrm{hr}$ at $100^{\circ}$ (Elliott, 1962). Ribitol and glycerol were separated by chromatography on Whatman No. 1 paper by using the solvent system of Armstrong et al. (1958), and were detected by the method of Bean \& Porter (1959).

Sugars. Washed organisms (0.75 g. wet wt.) were suspended in $5 \mathrm{ml}$. of $2 \mathrm{~N}-$ sulphuric acid and treated as described by Davis \& Baird-Parker (1959). Sugars 
were separated by single-dimension chromatography on Whatman No. 1 filter paper by the solvent system of Colombo et al. (1960). Sugars were detected by using Roy's (1960) double spray technique.

Amino sugars. Washed organisms (0.75 g. wet wt.) were suspended in $5 \mathrm{ml}$. of $5 \mathrm{~N}-\mathrm{HCl}$ and incubated for 2 days at $37^{\circ}$; the $\mathrm{HCl}$ was removed under vacuum in a vacuum desiccator containing concentrated $\mathrm{H}_{2} \mathrm{SO}_{4}$ and $\mathrm{NaOH}$ pellets (Salton, 1959). The residues were dissolved in $3 \mathrm{ml}$. of $10 \%(\mathrm{v} / \mathrm{v})$ isopropanol in water and several drops of sp.gr. 0.880 ammonia added to neutralize remaining acid. After filtration through no. 4 porosity sintered glass filters, the filtrates were evaporated to dryness on a steam-bath and the residues dissolved in $0.3 \mathrm{ml}$. of $10 \%(\mathrm{v} / \mathrm{v})$ isopropanol in water. The amino sugars were separated by chromatography on Whatman No. 1 filter paper by using the solvent system of Heyworth, Perkins \& Walker (1961) and detected by using Elson \& Morgan's (1933) spray.

Peptides and amino acids extractable by acetic acid. Acetic acid extracts of whole organisms were shown by Mattick et al. (1956) to be of use in identifying bacteria. The procedure was to suspend $0.5 \mathrm{~g}$. wet weight washed organisms in $5 \mathrm{ml}$. of $10 \%$ $(\mathrm{v} / \mathrm{v})$ glacial acetic acid and to leave at room temperature for 1-2 $\mathrm{hr}$ with occasional shaking. The extracts were centrifuged at $10,000 \mathrm{~g}$ to remove solids and the supernatant fluids evaporated to dryness in a rotary vacuum evaporator; the residues were finally suspended in $\mathbf{0 . 3} \mathrm{ml}$. volumes of $10 \%(\mathrm{v} / \mathrm{v})$ isopropanol in water. The amino acids and low molecular weight peptides were separated by chromatography on Whatman No. 1 paper by using the solvent system of Davis \& Freer (1960) and detected with the ninhydrin + collidine spray used for amino acids.

Electrophoretic separation of cell proteins. Starch gels (Smithies, 1955) were prepared by dissolving $15 \%(\mathrm{w} / \mathrm{v})$ Connaught Brand hydrolysed starch in a semidiscontinuous buffer system containing $90 \%(\mathrm{v} / \mathrm{v})$ tris + citrate buffer (pH 8.68) and $10 \%(\mathrm{v} / \mathrm{v})$ borate buffer (pH 8.2); both buffers used were described by Poulik (1957) but $\mathrm{LiOH}$ replaced the $\mathrm{NaOH}$ specified in the original borate buffer (Mr A. L. Ogden, personal communication). The concentrated cell-content fractions were applied to strips of Whatman No. 17 filter papers $(1.5 \mathrm{~cm} . \times 6 \mathrm{~mm}$.) and inserted $30 \mathrm{~mm}$. from the cathode end of a gel $190 \mathrm{~mm}$. long. A potential of $440 \mathrm{~V}$ and a current of $30 \mathrm{~mA}$ was applied along the gel, and electrophoresis continued until the moving boundary had migrated $80 \mathrm{~mm}$. past the inserts. Protein bands were developed by staining slices of gel for $1 \mathrm{~min}$. in a saturated solution of naphthalene black in methanol + water + glacial acetic acid $(5+5+1$ by vol.) followed by decolorization in several washes of the same solvent.

\section{RESULTS}

Preliminary examination of the morphology and catalase production of the organisms received showed that some had been incorrectly classified. Amongst these were three plasma-clotting strains of Streptococcus faecalis which had been sent to the author as coagulase-positive staphylococci and two other strains of $S$. faecalis, one of which had been identified as a coagulase-negative staphylococcus while the other had been named Micrococcus freudenreichii. Other wrongly classified organisms included several corynebacteria and unidentified Gram-negative rods; a strain of Serratia marcescens was received as a culture of $M$. roseus; a yeast was 
received labelled as a micrococcus as were two strains of Aerococcus (Pediococcus) viridans. Several Gram-positive and catalase-positive cocci were also found to have been mis-classified as regards their genus or species.

\section{Classification of organisms according to Baird-Parker (1963)}

Five hundred and sixty-four of the cultures studied were Gram-positive catalase-positive cocci. With the exception of the pink micrococci, representatives of which had not been previously studied, almost all of the strains could be classified into the Baird-Parker (1963) groups and subgroups. To accommodate these pink pigmented organisms, a further subgroup, Micrococcus subgroup 8, was introduced. Characters of the fourteen subgroups are shown in Table 2.

\section{Group 1 (Staphylococcus Rosenbach)}

Organisms placed in this group grew and produced acid from glucose when incubated under anaerobic conditions in a mineral salts + yeast-extract medium containing bromocresol purple as $\mathrm{pH}$ indicator (Baird-Parker, 1963). With two exceptions, the morphological and physiological characters of the 180 cultures classifiable into this group agreed with previously studied cultures; i.e. they were usually small cocci $(0.5-1.5 \mu)$ growing as irregular clusters and producing on agar smooth convex colonies pigmented white, yellow or orange; their physiological characters included growth usually at $45^{\circ}$ and sometimes at $10^{\circ}$. They also usually hydrolysed hippurate, proteins, fats and Tweens, and produced acid from galactose, glucose, glycerol, lactose, maltose, mannose and mannitol but not from arabinose, cellobiose, inositol, raffinose or xylose. Other characters included the ability of most strains to reduce nitrate beyond nitrite, and inability to hydrolyse aesculin or to grow on a medium containing ammonium phosphate as sole nitrogen source.

Characters of the subgroups within this group 1 also agreed closely with previous results. Exceptions were two otherwise typical subgroup II organisms which did not form acid from maltose and eight cultures which were acetoin-negative; four of the latter could be classified as acetoin-negative variants of subgroup V or VI. Of the four remaining acetoin-negative organisms only two possessed characters typical of staphylococci. One was coagulase-negative but similar to the coagulasepositive subgroup I organisms in the production of phosphatase and the formation of acid from mannitol in presence of air. However, it differed from sub-group I organisms by not coagulating human or rabbit plasma or forming acid from mannitol anaerobically. The other strain was phosphatase-negative and, of the sugar series tested, produced acid only from galactose, glucose and lactose.

The two apparently atypical staphylococci, both members of Abd-El-Malek and Gibson's group IIIB (NCTC 7567, 7568) appeared to be cocci when first examined. Characters which made me suspect that these were not staphylococci were: good growth on a medium containing ammonium phosphate as sole nitrogen source, hydrolysis of aesculin but not protein, fat, Tweens or hippurate, and formation of acid from a wide range of carbohydrates, including arabinose, cellobiose and xylose. On further examination of the cell morphology of these two organisms it was found that impression preparations of cultures grown for $4 \mathrm{hr}$ on nutrient agar contained mainly short paired rods and that organisms examined in the electron microscope were 


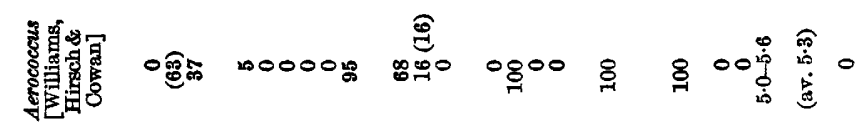

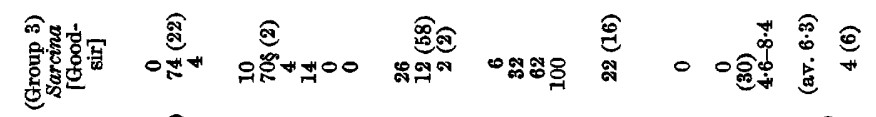

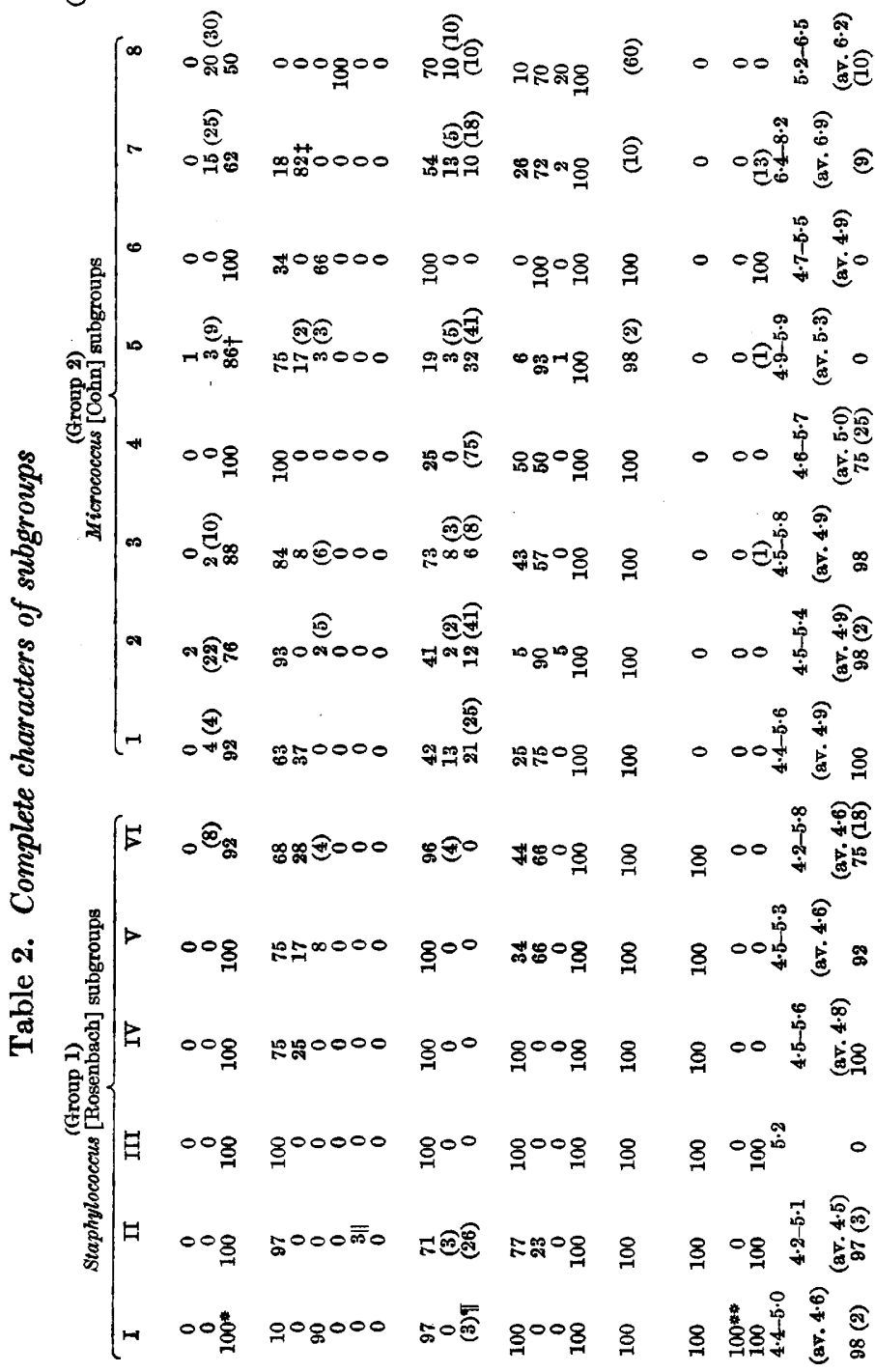

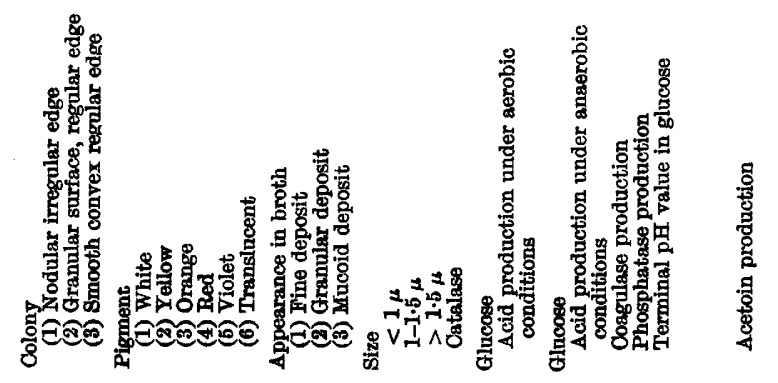




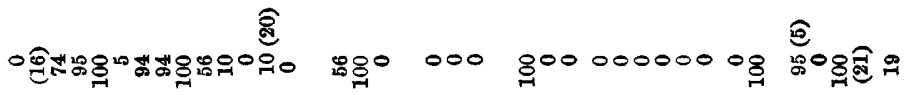

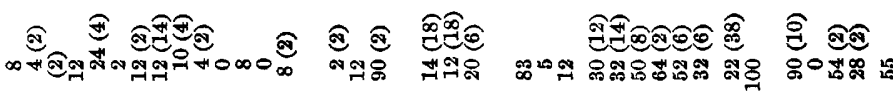

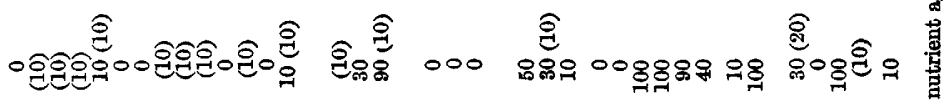

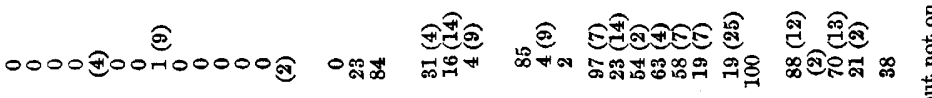

氕

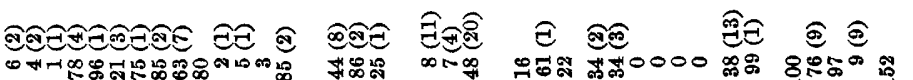

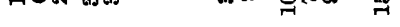

go

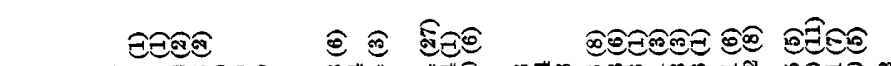

000맴ㅇำ

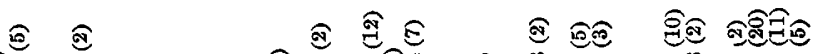

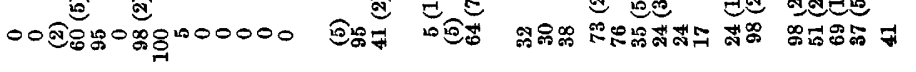

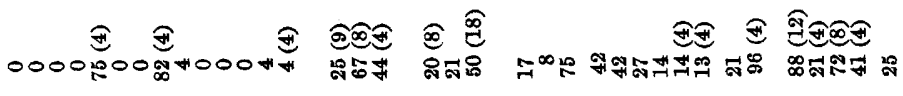

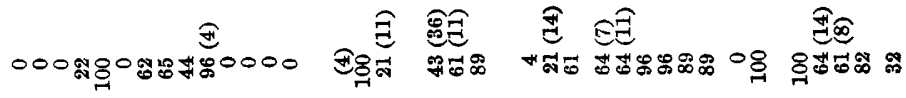

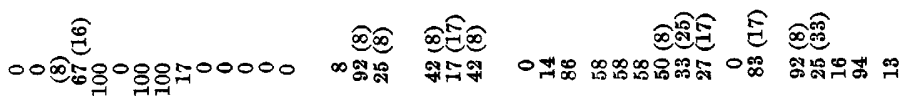

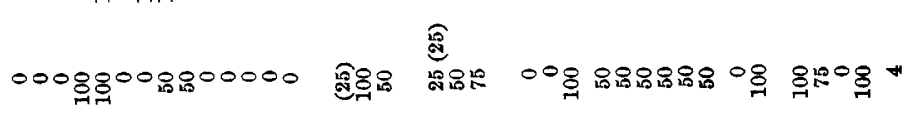

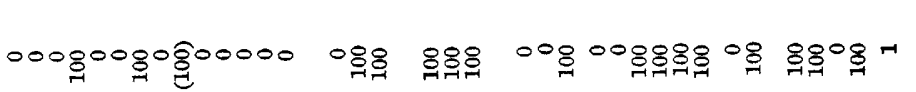

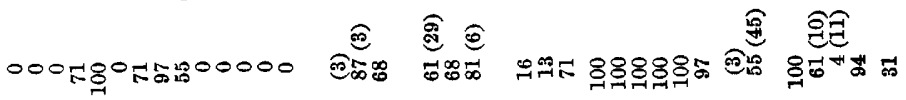

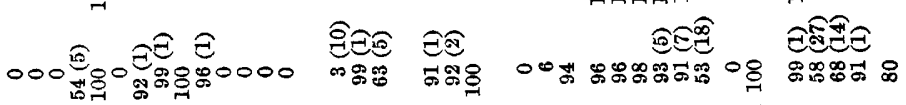

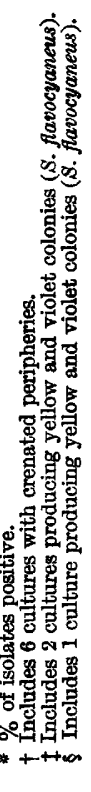


definitely rod-like. In their paper Abd-el-Malek \& Gibson (1948) mentioned that they were heat-resistant (survived $60^{\circ}$ for $30 \mathrm{~min}$.), were unable to grow at $37^{\circ}$ and formed colonies with a greenish-yellow pigment. These characters made me suspect that the two organisms were microbacteria. A culture of Microbacterium lacticum (NCDo 747) was examined and although it was morphologically distinguishable from Abd-el-Malek and Gibson's two strains it possessed very similar biochemical characters. The results of cell-wall analyses supported the exclusion of these organisms from the genus Staphylococcus (see discussion of results of cell analyses).

\section{Group 2 (Micrococcus Cohn)}

Group 2 contains cocci which were either unable to produce sufficient acid from glucose to change the indicator bromocresol purple or which grew and produced acid from glucose only in presence of air. They were generally much more variable in size than the staphylococci and formed tetrads as well as irregular clusters of cocci. Their colonies were either smooth and convex or slightly granular and were pigmented white, yellow, orange, red, brown or violet. Their growth in broth was usually either a mucoid or granular precipitate, in contrast to the fine deposit produced by staphylococci.

The eight subgroups differed in their carbohydrate metabolism. Subgroups 1-3 (Baird-Parker, 1963) possessed similar characters to the staphylococci in forming acetoin and an end $\mathrm{pH}$ value in glucose broth of generally below $\mathbf{5 \cdot 0}$; subgroups 5 and 6 differed from these in attacking a wider range of carbohydrates with a higher end $\mathrm{pH}$ value in glucose broth without producing acetoin; subgroup 4 appeared to be intermediate. Subgroups 7 and 8 formed either no acid or only small amounts from glucose.

Some characters of these subgroups differed in some respects from those previously reported (Baird-Parker, 1963). Thus, 20-40\% of subgroups 1 and 2 hydrolysed one or more of the Tweens, whereas only weak activity was shown by one organism in the small collection studied previously. Also, a larger number of the members of these subgroups grew at $10^{\circ}$ but not at $45^{\circ}$. With the exception of four organisms, the 72 cultures classifiable in Micrococcus subgroup 3 could be placed in one or other of the three types previously defined within this subgroup (BairdParker, 1963). One of the acetoin-negative organisms was placed in this subgroup rather than with the acetoin-negative subgroups since it hydrolysed Tweens and did not utilize arabinose, xylose or aesculin. The characters of subgroup 5 were mainly the same as those found previously, but the subgroup 6 members, the phosphatase-positive micrococci, were different in that most strains did not hydrolyse Tweens. The pink micrococci placed in subgroup 8 were very similar morphologically and biochemically to subgroup 7 members, but generally differed from the latter in producing more acid from glucose and utilizing a wider range of carbohydrates (see Table 2 ).

\section{Group 3 (Sarcina Goodsir)}

Members of this group grew as regular packets of eight or more cocci. Their physiological characters showed quite wide variations but the majority were similar to Micrococcus subgroup 7 or 8. 


\section{Relationship of my classification to previous taxonomic groupings}

One hundred and ninety-four named cultures were examined and, of these, 178 were established to be Gram-positive catalase-positive cocci. These belonged to

Table 3. Classification of named species, groups and subgroups according to classification of Baird-Parker (1963)

\section{Classification}

according to

Baird-Parker

(1963)

Staphylococcus

Subgroup I

Subgroup II

Subgroup III

Subgroup IV

Subgroup V

Subgroup VI

Micrococcus

Subgroup 1

Subgroup 2

Subgroup 3

Subgroup 5

Subgroup 6

Subgroup 7

Subgroup 8

Sarcina
Original classification

S. aureus (24)*

$S$. albus (2), S. epidermidis, S. saprophyticus (2)1, M. aurantiacus, M. violagabriellae (S. saprophyticus ${ }^{1}, S$. epidermidis ${ }^{2}$ )

M. hyicus (S. lactis $^{1}$ )

S. epidermidis

S. albus, S. epidermidis ${ }^{2}$, S. saprophyticus (2)1, M. cerolyticus (M. conglomeratus $\left.{ }^{2}\right)$

S. albus (S. lactis $\left.{ }^{1}\right)$, S. epidermidis $(2)^{2}$, S. saprophyticus $(2)^{1}$

S. epidermidis, $S$. saprophyticus (3) ${ }^{1}$

S. saprophyticus (S. epidermidis ${ }^{2}$ )

M. candicans (2) (S. saprophyticus ${ }^{1}$, S. epidermidis $\left.{ }^{2}\right)$, M. candidus (2) (S. saprophyticus $^{1}$, S. epidermidis $\left.{ }^{2}\right)$, S. albus (2) (S. saprophyticus ${ }^{1}$, S. epidermidis ${ }^{2}$ ) $M$. aurantiacus ( $S$. lactis $\left.{ }^{1}\right), M$. conglomeratus $(2)^{2}, M$. euryhalis $\left(M\right.$. varians $\left.{ }^{2}\right)$, $M$. varians $(10)^{2}$, S. lactis $(3)^{1}$, Sarc. aurantiaca $\left(S\right.$. lactis $\left.^{1}\right),\left(\right.$ M. conglomeratus $\left.{ }^{2}\right)$, Sarc. lutea (2) (S. lactis ${ }^{1}, M$. luteus $^{2}$ ). Abd-el-Malek \& Gibson's (1948) group III A (4) (S. lactis $^{2}$ ); Pohja's subgroups e, i, l, g, d, k, c.

$M$. varians $(3)^{2}, S$. lactis ${ }^{1}$, Pohja's subgroup $\mathrm{f}$

M. agilis (S. afermentans $\left.{ }^{1}\right), M$. flavus (5) (M. luteus $\left.(5)^{2}\right), M$. luteus $(8)^{2}, M$. lysodeikticus (4) (S. afermentans $(3)^{1}, M$. luteus ${ }^{2}$ ), M. sodonensis (M. luteus ${ }^{2}$ ), S. afermentans ${ }^{1}$, S. flavocyaneus (3) (S. afermentans ${ }^{1}, M$. luteus (2) ${ }^{2}$ ), Sarc. flava (2) (S. afermentans ${ }^{1}, M$. luteus $\left.{ }^{2}\right)$, Sarc. lutea (M. luteus ${ }^{2}$ ), Abd-el-Malek \& Gibson's group II B (S. afermentans ${ }^{1}$ ), Abd-el-Malek \& Gibson's group IIC (S. afermentans $\left.{ }^{1}\right)$

M. agilis (2) (S. afermentans (2) $\left.{ }^{1}\right)$, M. roseus (2) (S. roseus $\left.(2)^{1}\right)$, Pohja's subgroup $\mathbf{h}$

Sarc. aurantiaca (M. luteus $\left.{ }^{2}\right)$, Sarc. citrea (M. luteus $\left.{ }^{2}\right)$, Sarc. flava (2) (S. afermentans ${ }^{1}, M$. luteus ${ }^{2}$ ), Sarc. lutea (4) (S. afermentans (2) ${ }^{1}, M$. luteus (2)1), Sarc. marginata $\left(M\right.$. luteus $\left.{ }^{2}\right)$, Sarc. variabilis $\left(M\right.$. luteus $\left.{ }^{2}\right)$, M. corralinus (S. roseus $\left.{ }^{1}\right), M$. citreus $\left(M\right.$. luteus $\left.{ }^{2}\right)$ M. flavus (4) $M$. luteus $(4)^{2}, M$. flava-roseus (S. roseus ${ }^{1}$ ), M. luteus $(8)^{2}, M$. roseus (4) (S. roseus $\left.(4)^{1}\right), M$. rubens (S. roseus $\left.{ }^{1}\right)$

Organisms possessing characters that were very different from their original descriptions: Staphylococcus subgroup I: S. epidermidis $(7)^{2}$, S. epidermidis-albus (1) (S. aureus $\left.{ }^{1}\right)$, S. lactis ${ }^{1}$, M. caseolyticus (S. aureus ${ }^{1}$ ); subgroup II: S. aureus; Micrococcus subgroup 1: M. cremoris-viscosi (S. lactis $^{2}$ ), M. citreus; subgroup 2: M. caseolyticus; subgroup 3: M. luteus (2) (S. saprophyticus ${ }^{1}$, $M$. conglomeratus ${ }^{2}$ ); subgroup 5: Sarc. ventriculi (M. conglomeratus $^{2}$ ); subgroup 6: S. aureus; subgroup 7: $M$. candicans (S. afermentans ${ }^{1}$ ), $M$. freudenreichii (S. afermentans ${ }^{1}$ ), $M$. papyroabsorbens ( $S$. lactis $^{1}$ ); subgroup 8: $M$. varians.

Key:

$(24) *=$ no. of strains studied.

(S. saprophyticus ${ }^{1}$ ) Reclassified according to the classification of Shaw et al. (1951) by either the National Collection of Type Cultures (Dr S. T. Cowan) or the National Collection of Dairy Organisms (Dr E. I. Garvie).

(S. epidermidis $^{2}$ ). Reclassified according to the classification of Kocur \& Martinec (1962) by Dr M. Kocur of J. E. Purkyne University, Brno, Czechoslovakia. 
9 named species of staphylococci, 25 of micrococci, 9 of sarcinas and 12 to groups or subgroups within these genera. Table 3 shows the relationship of these taxa to each other and to the author's groups and subgroups.

The majority of the named species and groups were received through the generosity of Dr S. T. Cowan (Curator of the National Collection of Type Cultures), Dr Ellen I. Garvie (Curator of the National Collection of Dairy Organisms) and Dr M. Kocur (Curator of the Culture Collection of J. E. Purkyne University, Brno, Czechoslovakia). The first two of these sources have reclassified the cultures in their collections according to the scheme of Shaw et al. (1951) and the last according to that of Kocur \& Martinec (1962). Therefore, to indicate in Table 3 where organisms have been renamed by one or other of these sources, the original name is given followed by the new name in parentheses with a superscript referring to the source of this name. Where the same strain was received from more than one source only one is recorded in Table 3. Also, to avoid confusion, strains whose characters did not in any way correspond to their published descriptions are listed at the end of the Table.

\section{Relationship of classification to habitat}

Three hundred and twelve coagulase-negative, Gram-positive catalase-positive cocci were received as isolates from known sources. Table 4 shows the distribution of isolates from habitats from which ten or more organisms were received. For ease of interpretation, the numbers of each subgroup are expressed as a percentage of the total number of isolates from a particular source.

Table 4. Percentage distribution of coagulase-negative Gram-positive catalase-positive cocci from different sources

\begin{tabular}{|c|c|c|c|c|c|c|c|c|c|c|c|}
\hline & & & nan & & & Dairy & & & & & \\
\hline & $\begin{array}{l}\text { Sub- } \\
\text { group }\end{array}$ & Nose & Skin & Air & Soil & $\begin{array}{l}\text { pro- } \\
\text { ducts }\end{array}$ & $\begin{array}{c}\text { mented } \\
\text { Meats }\end{array}$ & Marine & Bacon & Brine & Pork \\
\hline Staphylococcus & II & 62 & 40 & 4 & $\mathbf{0}$ & $\mathbf{0}$ & $\mathbf{0}$ & $\mathbf{0}$ & 0 & $\mathbf{0}$ & $\mathbf{0}$ \\
\hline & IV & $\mathbf{0}$ & 8 & $\mathbf{0}$ & $\mathbf{0}$ & $\mathbf{0}$ & $\mathbf{0}$ & 10 & $\mathbf{0}$ & $\mathbf{0}$ & $\mathbf{0}$ \\
\hline & $\mathbf{V}$ & 5 & 4 & 8 & $\mathbf{0}$ & $\mathbf{0}$ & $\mathbf{0}$ & $\mathbf{0}$ & $\mathbf{0}$ & $\mathbf{0}$ & $\mathbf{0}$ \\
\hline & VI & 0 & 32 & 6 & 16 & 0 & $\mathbf{0}$ & 20 & 2 & $\mathbf{0}$ & 4 \\
\hline Micrococcus & 1 & 0 & 4 & 4 & 8 & 12 & $\mathbf{0}$ & 5 & 8 & 0 & 20 \\
\hline & 2 & 18 & 4 & 14 & 0 & 19 & $\mathbf{0}$ & 5 & 4 & 8 & 32 \\
\hline & $\mathbf{3}$ & $\mathbf{0}$ & 4 & 46 & 44 & 12 & $\mathbf{0}$ & 10 & $\mathbf{0}$ & 4 & 11 \\
\hline & 4 & 0 & 0 & $\mathbf{0}$ & $\mathbf{0}$ & 0 & $\mathbf{0}$ & $\mathbf{0}$ & 4 & $\mathbf{0}$ & $\mathbf{2}$ \\
\hline & $\mathbf{5}$ & 5 & 4 & 4 & 16 & 19 & 70 & 20 & 82 & 88 & 27 \\
\hline & 6 & 0 & $\mathbf{0}$ & 2 & 0 & 7 & 10 & 10 & 0 & 0 & 0 \\
\hline & 7 & $\mathbf{5}$ & $\mathbf{0}$ & $\mathbf{0}$ & 16 & $\mathbf{0}$ & 10 & $\mathbf{5}$ & $\mathbf{0}$ & $\mathbf{0}$ & 4 \\
\hline & 8 & 0 & $\mathbf{0}$ & $\mathbf{0}$ & $\mathbf{0}$ & $\mathbf{0}$ & 10 & $\mathbf{5}$ & $\mathbf{0}$ & $\mathbf{0}$ & $\mathbf{0}$ \\
\hline Sarcina & & 5 & $\mathbf{0}$ & 12 & 16 & 31 & 0 & 10 & $\mathbf{0}$ & $\mathbf{0}$ & $\mathbf{0}$ \\
\hline Total organism & & 21 & 25 & 48 & 12 & 16 & 10 & 19 & 46 & 55 & 44 \\
\hline
\end{tabular}

Staphylococci predominated among the Gram-positive catalase-positive cocci obtained from human skin and nasal surfaces, whereas micrococci occurred more frequently amongst isolates from air, soil, meat and dairy produce. The predominance of Staphylococcus subgroup II and VI organisms on human skin confirms 
previous results (Baird-Parker, 1962), as also does the finding that members of Micrococcus subgroup 3 are the main micrococci occurring in air samples (BairdParker, unpublished). The only coagulase-negative staphylococci received from marine sources were isolates from the skin of freshly-caught cod and herring.

\section{Relationship of classification to chemical components of the cell}

Forty-six strains, representative of my groups and subgroups, were examined for chemical components of the cells. Three main cell fractions were examined: whole organisms for sugars, amino sugars and acetic acid-extractable small peptides and amino acids; cell walls for amino acids and teichoic acids; cell contents for proteins.

The cell-wall mucopeptide of all strains contained alanine, glutamic acid and lysine, together with, in most strains varying amounts of aspartic acid, glycine and serine, and in some strains small amounts of leucine, threonine and valine. The results (Table 5) show only small differences in the overall peptide composition of the subgroups. There does, however, appear to be a simplification in the amino acid composition of the peptides as one proceeds from Staphylococcus subgroups I and II containing up to 9 amino acid components, through the other staphylococcus and micrococcus subgroups to Micrococcus subgroup 8 containing only 4 or 5 amino acids.

Other than ribose, glucose was the only sugar detected in staphylococci and Micrococcus subgroups 1-4, whereas glucose, galactose and/or mannose were present in many of the strains belonging to Micrococcus subgroups 5-8 and Sarcina (Table 5). Thus, with respect to sugars, there was an increase in complexity from Staphylococcus subgroup I containing little or no sugar other than ribose to Micrococcus subgroup 8 containing ribose and quite large amounts of glucose, galactose and mannose. Glucosamine and muramic acid were present in all the strains examined, with galactosamine in most strains. Variable amounts of teichoic acids were present in the cell walls of most strains but were not detected in walls of either Micrococcus subgroup 7 and 8. Glycerol-containing teichoic acids were most commonly found, although these were replaced by ribitol-teichoic acids in Staphylococcus subgroup I. Small amounts of ribitol were detected together with glycerol in two members of Micrococcus subgroup 2 (Table 5).

Differences in acetic acid-extractable amino acids and peptides were determined by comparing the patterns of ninhydrin-staining spots on two-dimensional chromatograms; no attempt was made to determine the position of individual amino acids by markers or the structure of the peptides by hydrolysis. Two main patterns were distinguishable. One was typical of most staphylococci, members of Micrococcus subgroups 1-3 and some members of Micrococcus subgroups 5 and 6 . The other was shown by the majority of strains of Micrococcus subgroup 5 and all strains belonging to Micrococcus subgroups 7 and 8 and Sarcina.

Electrophoresis of proteins from cell contents yielded a variety of distinct patterns of protein bands. Some of these patterns appeared to be characteristic of certain subgroups, e.g. Staphylococcus subgroups II, III, IV and V and Micrococcus subgroup 8. Other subgroups, however, gave a variety of patterns within a subgroup, e.g. Staphylococcus subgroups I and VI. 


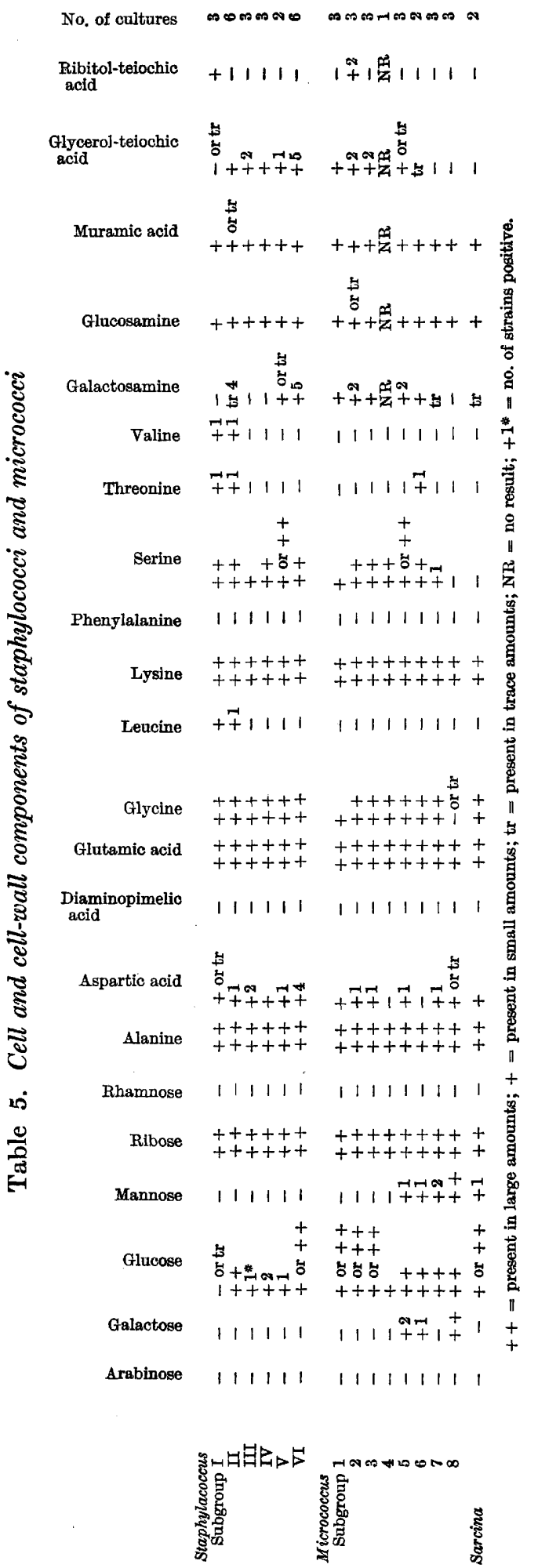




\section{DISCUSSION}

A detailed examination was made of the morphology and physiological characters of 607 cocci isolated from different sources and parts of the world. Before this work began, each strain was examined to determine its morphology, stainability by Gram's method and catalase production; this was done to exclude strains which did not correspond to the description: Gram-positive and catalase-positive coccus dividing in more than one plane. One or more of these characters was absent from forty-three of the strains examined. From this examination, there would appear to be two main sources of error in identifying Gram-positive catalase-positive cocci. Thus, cocci can be confused with Gram-positive and Gram-negative rods, with short chains of cocci and with budding yeasts, while citrate-utilizing plasma-clotting strains of faecal streptococci may be identified as coagulase-positive staphylococci. For several reasons it is considered that several of the established Micrococcus species are not true members of the Micrococcaceae. Thus, M. denitrificans, which is Gram-negative and forms rods in young cultures (Verhoeven, 1957), has a cellwall mucopeptide which contains a wide range of amino acids characteristic of Gram-negative genera (Baird-Parker, unpublished). In a recent paper Pleva \& Kocur (1963), regarded M. denitrificans as a valid member of the genus Micrococcus although they found that it showed definite rods when examined in the electron microscope. The related species $M$. halodenitrificans is also Gram-negative(Robinson \& Gibbons, 1952) and also possesses a characteristic Gram-negative cell wall with respect to both its high lipoprotein content (Smithies, Gibbons \& Bayley, 1955) and its wide range of amino acids (Takahashi \& Gibbons, 1959). It is also probable that $M$. radiodurans should be reclassified since its cell wall contains lipoprotein and a wide range of amino acids (Work, 1964); the guanine: cytosine ratio of its nucleic acid is also more like to that of the Gram-negative genera (Dr B. Moseley, personal communication). The probable identity of Abd-el-Malek \& Gibson's group IIIB with the genus Microbacterium on the grounds of morphology and physiological characters has already been mentioned; further evidence for excluding these organisms from the Micrococcaceae is the presence of diaminopimelic acid in their cell walls (Baird-Parker, unpublished).

The non-capsulate cocci which form short chains and grow on salt-containing media, i.e. the faecal streptococci, are frequently confused with coagulase-positive and -negative staphylococci. They are most readily distinguished from the clusterforming members of the Micrococcaceae by the catalase test (Isaacs \& Scouller, 1948; Evans, Buettner \& Niven, 1952; Brown \& Evans, 1963) and although there are a few reports of catalase-positive faecal streptococci (Langston, Guttierez \& Bouma, 1960) and of catalase-negative staphylococci (Lucas \& Seeley, 1955; Jensen, 1963; Solomon \& San Clemente, 1963) these reports are rare. Another group of organisms which may be confused with the staphylococci are the aerococci. The latter were originally reported to be catalase-negative but they may decompose hydrogen peroxide under certain conditions (Günther \& White, 1961). Also, Clausen (1964) reported the isolation of an Aerococcus sp. (A. catalasicus) which was nitratase-positive and catalase-positive. It may be necessary, therefore, to use tests other than catalase formation to distinguish these organisms from staphylococci and micrococci. They can be distinguished from micrococci by their fermentative meta- 
bolism (Cowan \& Steel, 1961) and from the staphylococci by their failure to hydrolyse arginine, proteins, fats or Tweens (Table 2). Aerococci can also be distinguished from staphylococci and from pediococci, which only form catalase on low-glucose media (Felton, Evans \& Niven, 1953), by their formation of peroxide. The production of peroxide may be detected by streaking a suspected aerococcus across a heart-infusion agar plate seeded with Staphylococcus aureus and incubating at $20^{\circ}$ for 3-4 days. The production of peroxide is indicated by inhibition of the staphylococcus in a wide zone surrounding the aerococcus growth; a control plate containing catalase should also be set up, to exclude inhibition due to antibiotic production (Baird-Parker, unpublished).

\section{CLASSIFICATION}

The majority of organisms which satisfied the criteria of morphology and catalase production could be classified into the groups and subgroups previously defined (Baird-Parker, 1963). Excluding the pink pigmented micrococci, over $96 \%$ of the remaining organisms could be classified into my thirteen subgroups. A further $3 \%$ of the organisms differed from previously defined subgroups in one main character only and were therefore considered to be variants of these subgroups. Only two organisms, both staphylococci, were sufficiently different from those previously studied to suggest that they should be placed in further subgroups.

The results obtained support the separation of staphylococci from micrococci on ability to grow and produce acid from glucose in the absence of air. This character separates staphylococci as a group of potential pathogens or commensals which are characteristic of animal and human surfaces, from micrococci which are a group of mainly free-living saprophytes which are nutritionally less exacting and morphologically and biochemically more variable than the staphylococci. Contrary to my previous conclusions (Baird-Parker, 1963), to place the packet-forming cocci in the genus Sarcina (group B) could not be justified. This reversal of my conclusions has resulted from a study of the morphology of named Sarcina spp. grown under a variety of conditions. When this was done, many of the named Sarcina spp. lost their ability to form packets. Of 55 organisms growing as regular packets of cocci on one or more media, only 20 invariably formed packets; under none of the combinations of media and temperature tested would they all form packets. It was further found that the pink-pigmented packet-forming cocci were indistinguishable biochemically and on their chemical constituents from the pink-pigmented micrococci of Micrococcus subgroup 8. Therefore, in agreement with Shaw et al. (1951) and Kocur \& Martinec (1962) it must be concluded that the ability to form cubical packets of cocci is characteristic of certain micrococci and that these, like the tetrad formers, belong mainly to Micrococcus subgroups 7 and 8 . In the following sections of this paper, the packet-forming cocci will be discussed with the micrococci.

Separation of the Gram-positive and catalase-positive cocci into two groups or genera is supported by the results of Thomas \& Schuhardt (1964), who examined the effect of lysostaphin (Schindler \& Schuhardt, 1964) on these organisms. They found that staphylococci (defined on ability to grow and produce acid from glucose anaerobically) were lysed by this substance but that the micrococci and sarcinas remained intact. 


\section{Group 1 (Staphylococcus Rosenbach)}

\section{Subgroup I (Staphylococcus aureus)}

The coagulase test is frequently used as sole criterion for recognizing Staphylococcus aureus. Ability to clot mammalian blood plasma is not, however, specific for $\boldsymbol{S}$. aureus and by no means all members of this species by clot plasma. Amongst Gram-negative species which may clot plasma, by citrate utilization or coagulase-like activity, are strains of Pseudomonas aeruginosa (Frédéricq, 1941), Serratia marcescens (Frédéricq, 1946) and Pasteurella pestis (Eisler, 1961), and amongst Gram-positive organisms are actinomycetes (Frédéricq, 1946) and strains of Streptococcus faecalis (Evans et al. 1952). The inability of $S$. aureus to clot plasma may be due to use of unsuitable plasma, the absence of bound and/or free coagulase (Duthie, 1954), or excessive production of fibrinolysin or a coagulase-destroying factor (Lominski, Smith \& Morrison, 1953; Munch-Peterson, 1961). The need to control the coagulase test was shown by the finding that seven strains designated as Staphylococcus epidermidis on inability to clot human blood plasma were, when tested in this laboratory, found to be typical strains of $S$. aureus which were able to clot rabbit plasma, ferment mannitol and to produce phosphatase; similarly a strain received as $\boldsymbol{S}$. epidermidis had been misclassified because it produced bound coagulase (slide test) but not free coagulase (tube test). The inadvisability of relying solely on the coagulase test for the identification of $S$. aureus was also shown by the receipt of two diphtheroids and five strains of $S$. faecalis which had been classified by their isolators as strains of $S$. aureus because of ability to clot blood plasma. Amongst other strains of $S$. aureus which were examined and found to be of doubtful authenticity (see Table 3) was the propagating strain of phage type 73 (NCTC 8360). In a recent study of the physiological characters of the phagepropagating strains of $S$. aureus, Solomon \& San Clemente (1963) reported that phage type 73 showed neither coagulase nor phosphatase activity. Dr I. Lominski (Dr K. J. Steel, personal communication) has shown that this organism will clot sheep plasma but not human or rabbit plasma. When I tested this organism it was coagulase-negative with rabbit plasma but phosphatase-positive, able to utilize glucose and mannitol only in the presence of air, to produce acid from arabinose and grow on a medium containing ammonium phosphate as sole nitrogen source. These characters make the organism unlikely to be a strain of $S$. aureus, and according to my work it should be classified in Micrococcus subgroup 6.

Anaerobic utilization of mannitol and the coagulase test were considered by Mossel (1962) to be the most useful criteria for distinguishing Staphylococcus aureus from other staphylococci and micrococci. He found that $95 \%$ of coagulase-positive strains from clinical and non-clinical sources fermented mannitol. However, ability to form acid from mannitol anaerobically may depend on the source of organism, since White, Rattray \& Davidson (1963) reported that only $73 \%$ of bovine strains of $S$. aureus fermented mannitol. Also in a recent survey Cowan \& Steel (1964) found that only $75 \%$ of the coagulase-positive staphylococci they tested were able to ferment mannitol under the conditions defined by Mossel (1962).

Our knowledge of variation in the physiological characters of Staphylococcus aureus indicates that a single character such as formation of coagulase cannot be solely relied upon for critical determination of this species. Therefore, before a 
coagulase-negative strain is classified with coagulase-negative staphylococci several further tests should be made to exclude the possibility that it is a coagulasenegative variant of $\boldsymbol{S}$. aureus. The best tests for this purpose are the determination of phosphatase production and mannitol fermentation. These tests when used in conjunction with the free and bound coagulase tests (Duthie, 1954) will clearly separate $S$. aureus from related staphylococci; positive recognition of this species is obtained when at least two of these tests are positive. Further confirmation of diagnosis can be obtained by determining phage typability (Parker, 1962), haemolysin pattern (Elek \& Levy, 1950) and ability to grow in normal human serum (Fletcher, 1962).

\section{Staphylococcus subgroups II and III}

Members of these subgroups produce phosphatase and are distinguished from Staphylococcus aureus by not forming acid from mannitol or coagulating plasma; they are separated by acid production from maltose and acetoin from glucose (Table 3). Staphylococci belonging to subgroup III have only been isolated from pig skin while members of Staphylococcus subgroup II have been isolated from several sources, although their main habitats would appear to be human and animal surfaces.

It has been suggested that ability to produce phosphatase is associated with pathogenicity and the coagulase test (Barber \& Kuper, 1951). However, the majority of coagulase-negative staphylococci from human sources are phosphatase producers (Baird-Parker, 1962; Jacobs, Willis \& Goodburn, 1963). Coagulasenegative staphylococci may, however, be associated with, and cause, a number of infective processes (Pereira, 1962). Two coagulase-negative pathogens studied by me were both phosphatase producers; one was a member of Staphylococcus subgroup II, the other of Staphylococcus subgroup III. The subgroup II organism was a strain of Micrococcus violagabriellae Castellani. This organism was isolated by Castellani (Castellani, 1955) from a chronic skin infection occurring in a group of South American marines and was shown by him to give rise to this condition on re-inoculation. Its physiological characters were identical with the apparently non-pathogenic subgroup II staphylococci that were isolated from human skin, but it possessed the additional property of producing a characteristic violet pigment when grown on glucose- or potato-containing media (Castellani, 1955; Steel, 1964). It should be mentioned that the strain studied did not have the same characters as those reported for $M$. violagabriellae by Kocur \& Martinec (1963a). Reclassification of $M$. violagabriellae in the genus Staphylococcus is in agreement with the results of Sneath (1960) and Kocur \& Martinec (1963a).

The other phosphatase-producing coagulase-negative pathogen studied was a strain of Micrococcus hyicus Sompolinsky. This was reported by Sompolinsky (1953) to be the causative organism in an outbreak of contagious impetigo of swine. It possesses similar physiological characters to the subgroup III staphylococci previously isolated from pig skin (Baird-Parker, 1963) but was unable to utilize glycerol (Table 2). M. hyicus produces necrotic lesions when subcutaneously injected into mice (Jones, Deibel \& Niven, 1963). I confirmed this observation but was unable to produce similar lesions with strains of Staphylococcus subgroup III isolated from pig skin. The physiological characters of $M$. hyicus were the same 
as those reported by Jones et al. (1963), and in support of their conclusions it is suggested that this organism should be transferred to the genus Staphylococcus. According to Jacobs et al. (1963) potentially pathogenic staphylococci produce deoxyribonuclease as well as phosphatase; this is true of $M$. hyicus (Jones et al. 1963). However, deoxyribonuclease activity was shown by several subgroup II staphylococci which $\mathrm{I}$ isolated from normal skin and by a number of saprophytic micrococci belonging to subgroups 2,5 and 7 . The correlation between deoxyribonuclease production and potential pathogenicity therefore requires further investigation.

\section{Staphylococcus subgroups $I V, V$ and $V I$}

Organisms received as strains of Staphylococcus albus, $S$. epidermidis and $\boldsymbol{S}$. saprophyticus were classified in subgroups IV, V and VI (Table 4). Staphylococcus subgroups IV and V possess physiological characters which suggest a relationship with either subgroup II or VI. Thus some strains of Staphylococcus subgroups IV were only separated from some members of subgroup VI by their inability to form acid from mannitol and subgroup $\mathrm{V}$ members from subgroup II by absence of phosphatase activity. In future considerations of species it is probable that subgroups IV and V will be combined with subgroups VI and II respectively. They are at present retained in separate subgroups as proteins electrophoretically separated from cell contents of members of these subgroups are quite distinct.

Members of Staphylococcus subgroup VI are separated from those of subgroup I, II and III by their aerobic utilization of mannitol and the absence of coagulase and phosphatase. They are characteristic of human and animal skins and were found amongst isolates from the skin of freshly-caught fish. However, their presence on fish skin may have occurred through handling of the skin before sampling.

\section{Group 2 (Micrococcus Cohn)}

\section{Micrococcus subgroups 1, 2, 3 and 4}

These subgroups are physiologically closely related and form acetoin as an end product of glucose metabolism. Strains of Staphylococcus epidermidis and $S$. saprophyticus were classified in these subgroups as also were cultures originally labelled $\boldsymbol{S}$. albus, $\boldsymbol{M}$. candicans and $\boldsymbol{M}$. candidus but which had been reclassified as either $S$. epidermidis or $S$. saprophyticus (Table 3). As mentioned previously (Baird-Parker, 1962, 1963) these subgroups contain organisms which are distinguished from staphylococci solely on their inability to use glucose under anaerobic conditions. It is with these organisms that the main controversy exists about separation of the Gram-positive catalase-positive cocci into two genera. Evidence can be cited which suggests classification with the staphylococci on the grounds of similar physiological characters and chemical composition, and with the micrococci on grounds of inability to grow anaerobically and to use glucose, and in a number of strains on the ability to produce acid from glucose in a medium containing ammonium phosphate as sole nitrogen source. Unfortunately, tests for anaerobic growth and glucose utilization are fairly critical and a result obtained by one method may not always agree with the result obtained by another method. Recently Cowan \& Steel (1964) tested methods which have been used for distin- 
guishing staphylococci from micrococci against a comprehensive collection of 87 strains of Gram-positive catalase-positive cocci. They found that $\mathbf{5 0}$ of these strains were classifiable as staphylococci by the Hugh \& Leifson (1953) test but only 35 of these were classifiable as staphylococci by Baird-Parker's test. Three tests correlated well: these were Baird-Parker's test, the test of Evans, Bradford \& Niven (1955), when

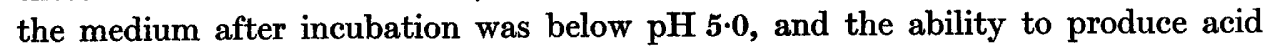
from glucose in a peptone medium incubated anaerobically.

A subcommittee set up by the International Association of Microbiological Societies is considering the methods for the separation of staphylococci from micrococci. At the first meeting of the subcommittee it was recommended that a standard test should be introduced to determine the anaerobic utilization of glucose and other carbohydrates by staphylococci. The method proposed was to inoculate growth from an actively growing culture into a tube of a semi-solid agar medium containing peptone + yeast extract + carbohydrate and bromocresol purple as $\mathrm{pH}$ indicator and to seal the tube with a layer of liquid paraffin. Tubes are incubated at $37^{\circ}$ for 5 days. If, when glucose is present, acid is produced throughout the tube, the organism is a staphylococcus; but if no acid is formed, or acid is only formed at the top of the tube, the organism is a micrococcus.

\section{Micrococcus subgroups 5 and 6}

Members of these subgroups oxidize a wider range of carbohydrates than those of subgroups 1-4 and are unable to form acetoin from glucose; the two subgroups are separated by phosphatase production. Subgroup 5 contains a large group of closely related organisms. These have been given a variety of specific names (see Table 3 ). Shaw et al. (1951) and Abd-el-Malek \& Gibson (1948) placed these organisms in Staphyloccus lactis and group IIIA respectively. Two of the most recent detailed classifications of the micrococci by Pohja (Pohja, 1960; Pohja \& Gyllenberg, 1962) and by Kocur \& Martinec (1962) have attempted to subdivide these micrococci into a number of subgroups or species. Pohja (1960) used 'numerical taxonomy' (Sneath, 1962 ) for his studies and subdivided his acetoin-negative micrococci into eleven subgroups; eight of these corresponded to my subgroups 5 and 6; the remainder were either halophilic or pink-pigmented. Primary division of these eight subgroups was based on salt tolerance and further division on optimum salt concentration and the production of acid from arabinose, and urease, gelatinase and nitratase activity. In a further paper Pohja \& Gyllenberg (1962) recognized six subgroups of halotolerant micrococci and distinguished these on the basis of optimum salt concentration and temperature for growth, the production of acid from arabinose and sorbitol and the hydrolysis of gelatin. Sneath (1962) pointed out that Pohja's subgroups were chosen mainly on arbitrary characters and it appears to me that many of the characters chosen by Pohja from cluster analyses are largely unstable ones. Thus, the salt tolerance of acetoin-negative micrococci can be increased by subculture in media containing increasing concentrations of sodium chloride and may be decreased by subculture in laboratory media of normal salt concentration (Baird-Parker, unpublished). Similarly, optimum temperature for growth is largely dependent on growth conditions. Kocur \& Martinec (1962) separated the halotolerant organisms belonging to my subgroups 5 and 6 into Micrococcus varians Migula, which forms acid from lactose and mannitol, and $\boldsymbol{M}$. conglomeratus Migula 
which does not attack either of these carbohydrates. However, in my experience, quite a number of the halotolerant glucose-oxidizing acetoin-negative micrococci oxidize lactose but not mannitol and vice versa. It must be concluded, therefore, that at present there is no satisfactory division of these organisms on physiological characters. It may be possible, however, to separate these organisms on their chemical compositions (Davison \& Baddiley, 1963).

\section{Micrococcus subgroups 7 and 8}

Members of subgroups 7 and 8 either do not release detectable acid when carbohydrates are utilized or produce only small amounts of acids from these substrates. They also differ from most other micrococci in their inability to grow in the presence of $10 \%$ sodium chloride. The two subgroups contain a variety of morphological types, ranging from the irregular clusters of cocci characteristic of the strongly glucose-oxidizing micrococci to the tetrad and the cubical packet formers which were classified in the genus Sarcina. The two subgroups are distinguished by the red or pink pigmentation of cocci placed in Micrococcus subgroup 8.

The separation of subgroups 7 and 8 solely on the grounds of pigmentation is difficult to justify in the light of observations by several workers that Micrococcus lysodeikticus, which is a member of subgroup 7, is able to give stable pink-pigmented mutants (Field \& Naylor, 1962; Dr G. W. Gould, personal communication). However, the cell-wall composition of the two subgroups is different (Table 5) as also are the proteins of their cell contents. It has also been shown by Eisenberg \& Evans (1963) that two typical members of subgroup 7, M. sodonensis and M. lysodeikticus, have quite different carbon and nitrogen requirements from $M$. roseus. Therefore on this evidence it would appear justifiable to separate subgroup 7 from subgroup 8 on pigmentation.

The wide variety of morphological and physiological types placed in subgroup 7 is paralleled by the large number of species in which these organisms have been placed (Table 3). Sarcina spp. classifiable in Micrococcus subgroup 7 include: $S$. aurantiaca, S. citrea, S. flava, S. lutea, S. marginata, S. variabilis. The endospore-forming organism originally called $S$. urea (Beijerinck) Löhnis possesses similar physiological characters to the packet-forming micrococci but has been shown by MacDonald (1962) to be related serologically and in DNA composition to the Bacillaceae. It has therefore been re-classified as Planosarcina ureae Beijerinck by MacDonald (1962) and Sporosarcina ureae (Beijerinck) Orla-Jensen by Kocur \& Martinec (1963b).

It is currently believed that intensive speciation of the weakly glucose-oxidizing micrococci is not justified and in recent classification they are placed in a single species. For example, Shaw et al. (1951) placed them in the species Staphylococcus afermentans ex Castellani and Kocur \& Martinec (1962) in the species Micrococcus luteus (Schröeter) Cohn. This latter name would appear to be more appropriate as it excludes the implication that they are unable to utilize sugars; results obtained by Rosypal \& Kocur (1963) by manometric techniques would indicate that they can all to some extent oxidize a variety of mono- and di-saccharides. Further, in detecting carbohydrate utilization by acid production, the medium used plays a large part in the result obtained (Cowan \& Steel, 1964). Thus, Shaw et al. (1951) and Rosypal Kocur \& Hodák (1963) were unable to show acid production from glucose by $M$. 
lysodeikticus growing in a peptone broth, although this organism will produce detectable acid when growing in a mineral-salt yeast-extract medium containing glucose.

\section{Chemical composition of cells in relationship to classification}

Several attempts have been made to use chemical components of micro-organisms for the classification of Gram-positive catalase-positive cocci. Cummins \& Harris $(1956 a, b)$ were able to divide nine named species of staphylococci, micrococci, sarcinas and aerococci into three groups according to differences in their cell-wall carbohydrates, amino acids and amino sugars. The first of these groups contained strains of Staphylococcus aureus, S. albus, S. citreus, Micrococcus luteus and Sarcina lutea; the second a strain of Micrococcus conglomeratus and strains of Aerococcus viridans and a third two red-pigmented organisms, $M$. cinnabarius and $M$. rhodochrous. However, as pointed out by Cummins \& Harris (1956b) these groupings cut right across the divisions of these organisms on morphological and physiological grounds. Thus, the second group of Cummins \& Harris is unlikely to be of taxonomic significance since it groups a typical microcococcus with strains of the physiologically very different $A$. viridans; their third group must also be disregarded as it contains two rod formers (Shaw et al. 1951; Cummins \& Harris, 1956a). It would appear, therefore, that only the first group of Cummins \& Harris is valid since it is the only one to contain only Gram-positive catalase-positive cocci. The characters of this group agree well with my results for a range of different physiological groups of staphylococci and micrococci (see Table 5) and indicate that qualitative differences in cell-wall sugars, amino sugars and amino acids are insufficient to distinguish well-defined groups of these organisms. Determination of these classes of compound is, however, of value in the separation of members of the Micrococcaceae from other coccus-forming genera. For example, I found, in agreement with the results of Salton \& Pavlick (1960), that $M$. varians (NCTC 7281) contained diaminopimelic acid (DAP) in its cell wall in place of the lysine characteristic of other micrococci studied. The strains of $M$. varians was also atypical with respect to its morphology and physiological characters and therefore requires reclassification. Also, DAP was found in the cell walls of members of Abd-el-Malek \& Gibson's group IIIB and $M$. radiodurans and $M$. denitrificans.

Qualitative differences in the composition of teichoic acids from the cell walls of staphylococci and micrococci were suggested by Davison \& Baddiley (1963) to be of use in the classification of these organisms. With the exception of the type culture of Staphylococcus saprophyticus (NCTC 7292) ribitol-containing teichoic acids were found only in the cell walls of strains of $S$. aureus; teichoic acids were absent or present only as the glycerol polymer in the other coagulase-negative strains studied. The authors suggested that this ribitol-containing strain of $S$. saprophyticus (a member of Micrococcus subgroup 3) is atypical and found that a recently isolated 'pathogenic' strain of this species possessed only glycerol-teichoic acid. However, the occurrence of ribitol-teichoic acid may not be so uncommon amongst coagulasenegative staphylococci since Losnegard \& Oeding (1963a) reported that two of four strains of $S$. epidermidis they examined contained ribitol-teichoic acids structurally and serologically related to the group A polysaccharide extractable from $S$. aureus (Losnegard \& Oeding, 1963b). Perhaps it is significant that both these organisms 
were isolated from urine. Davison \& Baddiley's (1963) results clearly show the presence of at least two distinct glycerol-teichoic acids in organisms classifiable in my Micrococcus subgroup 5. Further studies of teichoic acids may therefore aid the classification of these micrococci and form the basis for serological studies of coagulase-negative staphylococci; see Davison et al. (1964).

Quantitative differences in the cell-wall amino acids of Gram-positive catalasepositive cocci were examined by Salton \& Pavlik (1960), who found distinct differences in the molecular proportions of amino acids in the mucopeptides of staphylococci and micrococci; on a molecular basis the amount of glycine in the cell-wall mucopeptide of staphylococci was 4 times that present in the micrococci studied. The relative molecular proportions of lysine, glutamic acid, glycine and alanine were very similar for members of Micrococcus subgroup 7 (Sarcina lutea, S. flava, $M$. tetragenus and $\boldsymbol{M}$. lysodeikticus); these amino acids were different both in type and proportion in Micrococcus subgroup 8 (M. roseus). Studies of C-terminal and $\mathrm{N}$-terminal amino acids of the mucopeptide such as those mentioned by Salton (1960) may form an even finer taxonomic tool for classifying these organisms.

Gregory \& Mabbit (1957), as part of a study of acetic acid-extractable amino acids and peptides in the classification of micro-organisms, examined representatives of cocci classified according to the scheme of Shaw et al. (1951). They found that strains of Staphylococcus aureus were distinguishable from $S$. saprophyticus by their pattern of ninhydrin-staining peptides and amino acids, but that a variety of patterns was produced by $S$. lactis strains, some of which were similar to $S$. saprophyticus; $S$. roseus and $S$. afermentans were also not clearly separated. My results are mainly in agreement with those of Gregory \& Mabbit, but unlike them clear differentiation of strains corresponding to $S$. aureus and $S$. saprophyticus was not obtained and only two main groups could be distinguished (see Results). Two of the groups that Gregory \& Mabbit distinguished chromatographically within $S$. lactis were Abd-el-Malek \& Gibson's groups III A (Micrococcus subgroup 5) and IIIB. They found that the difference between chromatograms of these groups was greater than between the type strains of $S$. aureus and $S$. saprophyticus. This result would support my view that Abd-el-Malek \& Gibson's group III B organisms are not members of the Micrococcaceae.

Electrophoretic separation of proteins from cell contents by starch-gel electrophoresis and staining of the proteins to demonstrate esterase activity was shown by Norris (1962) to be of use in the classification of Bacillus spp. Rosenkast \& Clausen (1962) showed that the pattern of proteins separated by starch-gel electrophoresis of autolysed Staphylococcus aureus correlated with Cowan's three serological types. The present results indicate that the complex patterns of proteins separated electrophoretically from the cell contents of staphylococci and micrococci may be of value in the grouping of these organisms, but that further work along the lines used by Norris for Bacillus spp. may lead to more clear-cut results.

The author wishes to thank the many persons who generously gave the cultures that made this study possible, Mrs B. A. Hynd for her technical assistance and Mr W. E. Crabb for the preparation and running of starch gels. 
Abd-gl-Malek, Y. \& Gibson, T. (1948). Studies in the bacteriology of milk. II. The staphylococci and micrococci of milk. J. Dairy Res. 15, 249.

Anderson, J. I. W. (1962). Studies on micrococci isolated from the North Sea. J. appl. Bact. 25, 362.

Armstrong, J. J., Baddiley, J., Buchanan, J. G., Carss, B. \& Greenberg, G. R. (1958). Isolation and structure of ribitol phosphate derivatives (teichoic acids) from bacterial walls. J. chem. Soc. p. 43444.

Baird-Parker, A. C. (1962). The occurrence and enumeration, according to a new classification, of micrococci and staphylococei in bacon and on human and pig skin. J. appl. Bact. 25, 352.

Batrd-Parker, A. C. (1963). A classification of micrococci and staphylococci based on physiological and biochemical tests. J. gen. Microbiol. 30, 409.

BARBER, M. \& KUPER, S. W. A. (1951). Identification of Staphylococcus pyogenes by the phosphatase reaction. J. Path. Bact. 63, 65.

Bean, R. C. \& Ponter, G. G. (1959). Detection and differentiation of sugars and polyols on single paper chromatograms. Analyt. Chem. 31, 1929.

Brown, R. L. \& Evans, J. B. (1963). Comparative physiology of antibiotic-resistant strains of Staphylococcus aureus. J. Bact. 85, 1409.

Castellani, A. (1955). Note préliminaire sur un nouveau microcoque isolé d'une dermatite axillaire superficielle tropicale. Ann. Inst. Pasteur, 89, 475.

Clausen, O. G. (1964). The discovery, isolation and classification of various $\alpha$-haemolytic micrococci which resemble aerococci. J. gen. Microbiol. 35, 1.

Colombo, D., Conbetta, D., Pirotta, A., Ruffini, G. \& Sartori, A. (1960). A solvent for qualitative and quantitative determinations of sugars using paper chromatography. J. Chromatog. 3, 343.

Cowan, S. T. \& Steel, K. J. (1961). Diagnostic tables for the common medical bacteria. J. Hyg., Camb. 59, 357.

Cowan, S. T. \& SteEL, K. J. (1964). Comparison of differentiating criteria for staphylococci and micrococci. J. Bact. 88, 804.

Cummins, C. S. \& Harris, H. (1956a). The chemical composition of the cell wall in some Gram-positive bacteria and its possible value as a taxonomic character. J. gen. Microbiol. 14, 583.

Cummins, C. S. \& Harris, H. (1956b). The relationships between certain members of the Staphylococcus-Micrococcus group as shown by their cell wall composition. Int. Bull. bact. Nomencl. Taxon. 6, 111 .

Davis, G. H. G. \& Baird-Parker, A. C. (1959). The classification of certain filamentous bacteria with respect to their chemical composition. J. gen. Microbiol. 21, 612.

Davis, G. H. G. \& Freer, J. H. (1960). Studies upon an oral aerobic actinomycete. $J$. gen. Microbiol. 23, 163.

Davison, A. L. \& Baddiley, J. (1963). The distribution of teichoic acids in staphylococci. J. gen. Microbiol. 32, 271.

Davison, A. L., Baddilex, J., Hafstad, T., Losnegard, N. \& Oeding, P. (1964). Teichoic acids in the walls of staphylococci. Nature, Lond. 202, 872.

Duthre, E. S. (1954). Evidence for two forms of staphylococcal coagulase. J. gen. Microbiol. 10, 427.

Eisenberg, R. C. \& Evans, J. B. (1963). Energy and nitrogen requirements of $M$. roseus. Canad. J. Microbiol. 9, 633.

Eister, D. M. (1961). Coagulation of human plasma by Pasteurella pestis. J. Bact. 81, 241.

Elek, S. D. \& Levy, E. (1950). Distribution of haemolysins in pathogenic and nonpathogenic staphylococci. J. Path. Bact. 61, 541.

ELLrotT, S. D. (1962). Teichoic acid and the group antigen of Group D streptococci. Nature, Lond. 193, 1105.

Etson, L. A. \& Morgan, W. J. (1933). A colorimetric method for the determination of glucosamine and chondrosamine. Biochem. J. 27, 1824. 
Evans, J. B., Bradford, W. L. \& Niven, C. F., Jr. (1955). Comments concerning the taxonomy of the genera Micrococcus and Staphylococcus. Int. Bull. bact. Nomencl. Taxon. 5, 61.

Evans, J. B., Buettner, L. G. \& Niven, C. F., Jr. (1952). Occurrence of streptococci that give a false positive coagulase test. J. Bact. 64, 433 .

Felton, E. A., Evans, J. B. \& Nrven, C. F., Jr. (1953). Production of catalase by pediococci. J. Bact. 65, 481.

Fieid, A. K. \& NAYLOR, H. B. (1962). Induction of lysogenic Micrococcus lysodeikticus. J. Bact. 84, 1129.

Fuetcher, S. (1962). The growth of staphylococci in human serum. J. Path. Bact. 84, 327.

FrídéricQ, P. (1941). Des actions coagulants et fibrinolytiques du staphylocoque, du bacille pyocyanique et de leurs coagulases. Acta biol. belg. 1, 462 .

FrédéricQ, P. (1946). Sur la coagulation du plasma oxalaté pas les cultures d'actinomycètes. C. r. Seanc. Soc. Biol. 140, 1165.

GüNTHER, H. L. \& WHITE, H. R. (1961). The cultural and physiological characters of the pediococci. J. gen. Microbiol. 26, 185.

GrEGORY, M. \& MABBITT, L. A. (1957). The differentiation of bacterial species by paper chromatography. V. Preliminary examination of the micrococci. J. appl. Bact. 20, 226.

Heyworth, R., Perkins, H. R. \& Walker, P. G. (1961). Paper chromatography of hexosamines and $N$-acetylhexosamines. Nature, Lond. 190, 261.

HoAre, D. S. \& Work, E. (1957). The stereoisomers of $\alpha$-diaminopimelic acid. II. Their distribution in the bacterial order Actinomycetates and in certain Eubacteriales. Biochem. J. 65, 441.

Hugh, R. \& LeIfson, E. (1953). The taxonomic significance of fermentative versus oxidative metabolism of carbohydrates by various Gram-negative bacteria. J. Bact. 66, 24.

IsAACS, A. \& Scouluer, J. M. (1948). Catalase production by Gram-positive cocci: a simple test for differentiating enterocococci from micrococci. J. Path. Bact. 60, 135.

JacoBs, S. I., Willis, A. T. \& GoodBurn, G. M. (1968). Significance of deoxyribonuclease production by staphylococci. Nature, Lond. 200, 709.

JENSEN, J. (1963). Apocatalase of catalase-negative staphylococci. Science, 141, 45.

Jones, D., Deiber, R. H. \& Niven, C. F., Jr. (1963). Identity of Staphylococcus epidermidis. J. Bact. 85, 62.

Kocur, M. \& Martinec, T. (1962). A Taxonomic Study of the Genus Microcococcus. Brno (Czechoslovakia): Fac. Sci. Univ. Purkyně.

KocUr, M. \& MARTiNec, T. (1963a). The classification of some violet-pigmented micrococci. J. gen. Microbiol. 32, 185.

Kocur, M. \& Martinec, T. (1963b). The taxonomic status of Sporosarcina ureae (Beijerinck) Orla-Jensen. Int. Bull. bact. Nomencl. Taxon. 13, 201.

Langston, C. W., GutTierez, J. \& Bouma, C. (1960). Catalase-producing strains of streptococci. J. Bact. 80, 693.

Lominski, I., Smith, D. D. \& Morrison, R. B. (1953). A coagulase-destroying factor produced by variants of Staphylococcus aureus. Nature, Lond. 171, 214.

Losnegard, N. \& Oeding, P. (1963a). Immunochemical studies on polysaccharides from Staphylococcus epidermidis. I. Isolation and chemical characterization. Acta path. microbiol. scand. 58, 482.

LosNegard, N. \& Oeding, P. (1963b). Immunochemical studies on polysaccharides from Staphylococcus epidermidis: 2. Antigenic properties. Acta path. microbiol. scand. 58, 493.

Lucas, P. R. \& Seeley, H. W. (1955). A catalase negative Micrococcus pyogenes var. aureus. J. Bact. 69, 231.

MacDonald, R. E. (1962). Some further observations on the physiology and taxonomic position of Planosarcina ureae. Bact. Proc. p. G24.

Mattick, A. T. R., Cheeseman, G. C., Berridge, N. J. \& Bottazzi, V. (1956). The differentiation of species of lactobacilli and streptococci by means of paper partition chromatography. J. appl. Bact. 19, 310. 
Mossex, D. A. A. (1962). Attempt in classification of catalase-positive staphylococci and micrococci. J. Bact. 84, 1140.

Munch-Petersen, E. (1961). Staphylococcal coagulase. Zbl. Bakt. (1 Ref.) 178, 279.

NoRRIs, J. R. (1962). Electrophoretic analysis of bacterial esterase systems-an aid to taxonomy. J. gen. Microbiol. 28, vii.

Parker, M. T. (1962). Phage typing and the epidemiology of Staphylococcus aureus infection. J. appl. Bact. 25, 389.

Pereira, A. T. (1962). Coagulase-negative strains of staphylococcus possessing antigen 51 as agents of urinary infection. J. clin. Path. 15, 252.

Pleva, V. \& Kocur, M. (1963). Electron microscopy of the genera Micrococcus and Staphylococcus. Reports from conference on taxonomy of bacteria held at J. E. Purkynĕ University, Brno, Czechoslovakia. Brno: Pub. Fac. Sci. Univ. Purkyně No. 448.

PoHJa, M. S. (1960). Micrococei in fermented meat products. Classification and description of 171 different strains. Suom. Maataloust. Seur. Julk, no. 96, 1.

Pohja, M. S. \& Gyluenberg, H. G. (1962). Numerical taxonomy of micrococci of fermented meat origin. J. appl. Bact. 25, 341.

Poulik, M. D. (1957). Starch gel electrophoresis in a discontinuous system of buffers. Nature, Lond. 180, 1477.

Robinson, J. \& Gibbons, N. E. (1952). The effects of salts on the growth of Micrococcus halodenitrificans n.sp. Can. J. Bact. 30, 147.

Rosenkast, P. \& Clausen, J. (1962). Classification of Micrococcus (Staphylococcus aureus) by means of electrophoretic mobility of extractable protein. Experientia, 18, 293.

Rosypal, S. \& Kocur, M. (1963). The taxonomic significance of the oxidation of carbon compounds by different strains of Micrococcus luteus. Antonie van Leeurvenhoek, 29, 313.

Rosypal, S., Kocur, M. \& HoĎÁk, K. (1963). A study of violet-pigmented micrococci. Yellow-pigmented mutants of Staphylococcus flavocyaneus. J. gen. Microbiol. 32, 189.

Roy, J. K. (1960). A sensitive method for detecting sugars on paper chromatograms. Analyst, Lond. 85, 295.

Salton, M. R. J. (1959). An improved method for the detection of $\mathrm{N}$-acetylamino sugars on paper chromatograms. Biochim. biophys. Acta, 34, 308.

Salton, M. R. J. (1960). Microbial Cell Walls. London: John Wiley and Sons, Inc.

Salton, M. R. J. \& Horne, R. W. (1951). Studies of bacterial cell walls. II. Methods of preparation and some properties of cell walls. Biochim. biophys. Acta, 7, 177.

Salton, M. R. J. \& PavLik, J. G. (1960). Studies of the bacterial cell wall. VI. Wall composition and sensitivity to lysozyme. Biochim. biophys. Acta, 39, 398.

Schindler, C. A. \& Schunardt, V. T. (1964). Lysostaphin: a new bacteriolytic agent for the staphylococcus. Proc. natn. Acad. Sci., U.S.A. 51, 414.

Shaw, C., STitT, J. M. \& Cowan, S. T. (1951). Staphylococci at their classification. J. gen. Microbiol. 5, 1010.

SmItHIEs, O. (1955). Zone electrophoresis in starch gels: Group variations in the serum proteins of normal human adults. Biochem. J. 61, 629.

Smithies, W. R., Gibbons, N. E. \& Bayley, S. T. (1955). The chemical composition of the cell and cell wall of some halophilic bacteria. Can. J. Microbiol. 1, 605 .

SNeAth, P. H. A. (1960). A study of the bacterial genus Chromobacterium. Iorwa St. J. Sci. 34, 243.

Sneath, P. H. A. (1962). The construction of taxonomic groups. In Microbial Classification. Symp. Soc. gen. Microbiol. 12, 289.

Solomon, J. J. \& SAN Clemente, C. L. (1963). Some physiological characteristics of two sets of phage propagation strains of Staphylococcus aureus. Appl. Microbiol. 11, 36.

Sompolinsky, D. (1953). De l'impetigo contagiosa suis et du Micrococcus hyicus n.sp. Schreiz. Arch. Tierheilk. 95, 302.

STEEL, K. J. (1964). Micrococcus violagabriellae Castellani. J. gen. Microbiol. 36, 133.

Su, T.L. (1948). Micrococcin. An antibacterial substance formed by a strain of micrococcus. Br. J. exp. Path. 29, 473.

TAKahashi, I. \& GibBons, N. E. (1959). The effect of salt concentration on the morphology and chemical composition of M. halo-denitrificans. Can. J. Microbiol. 5, 25. 
Thomas, E. T. \& SchuhardT, V. T. (1964). Susceptibility of aerobic Micrococcaceae to lysostaphin. Bact. Proc. p. 23.

Verhoeven, W. (1957). In Bergey's Manual of Determinative Bacteriology (1957), 7th ed. Ed. by R. S. Breed, E. G. D. Murray \& N. R. Smith, p. 457. London: Baillière, Tindall and Cox.

White, F., Rattray, E. A. S. \& Davidson, D. J. (1963). Sensitivity to antibiotics and biochemical activities of serotypes of bovine staphylococci. J. comp. Path. 73, 21.

Work, E. (1964). Amino acids of walls of Micrococcus radiodurans. Nature, Lond. 201, 1107. 
